Review

\title{
Chemically Modified Cyclodextrins: An Attractive Class of Supramolecular Hosts for the Development of Aqueous Biphasic Catalytic Processes
}

\author{
Hervé Bricout ${ }^{1,2,3}$, Frédéric Hapiot ${ }^{1,2,3}$, Anne Ponchel ${ }^{1,2,3}$, Sébastien Tilloy ${ }^{1,2,3}$ and \\ Eric Monflier ${ }^{1,2,3, *}$
}

1 Univ Lille Nord de France, F-59000 Lille, France

2 UArtois, UCCS, Faculté des Sciences Jean Perrin, Rue Jean Souvraz, SP 18-62307 Lens Cedex F-62300 Lens, France; E-Mails: herve.bricout@univ-artois.fr (H.B.); frederic.hapiot@univ-artois.fr (F.H.); anne.ponchel@univ-artois.fr (A.P.); sebastien.tilloy@univ-artois.fr (S.T.)

3 CNRS, UMR 8181, F-59650 Villeneuve d'Ascq, France

* Author to whom correspondence should be addressed; E-mail: eric.monflier@univ-artois.fr; Tel.: +33-321-791-772; Fax: +33-321-791-755.

Received: 22 September 2009 / Accepted: 16 October 2009 / Published: 27 October 2009

\begin{abstract}
During these last years, cyclodextrins have contributed greatly to the development of catalytic processes in water. These cyclic oligosaccharides composed of $6(\alpha), 7(\beta)$ or $8(\gamma)$ glucopyranose units improve the mass transfer in aqueous-organic two-phase systems and are useful compounds to design new catalysts. Thus, chemically modified cyclodextrins can be used to: (i) increase significantly the rate and selectivity of reactions catalyzed by water-soluble organometallic complexes, (ii) design new water-soluble ligands for aqueous organometallic catalysis, (iii) stabilize catalytically active noble metal nanoparticles in water and (iv) favour the dispersion and activation of the palladium on charcoal in water.
\end{abstract}

Keywords: cyclodextrin; aqueous organometallic catalysis; nanoparticles; palladium on charcoal 


\section{Introduction}

During the past decade, ecological requirements have pressed chemists to develop clean catalytic processes and technologies. In this context, the immobilization of homogeneous or heterogeneous catalysts in an aqueous phase appears to be an environmentally friendly technique to produce organic compounds [1-5]. Indeed, the catalyst can be easily recovered in active form at the end of reaction by decantation of the aqueous and organic phases, and the production costs are significantly lower (Figure 1).

Figure 1. Principle of aqueous catalysis.

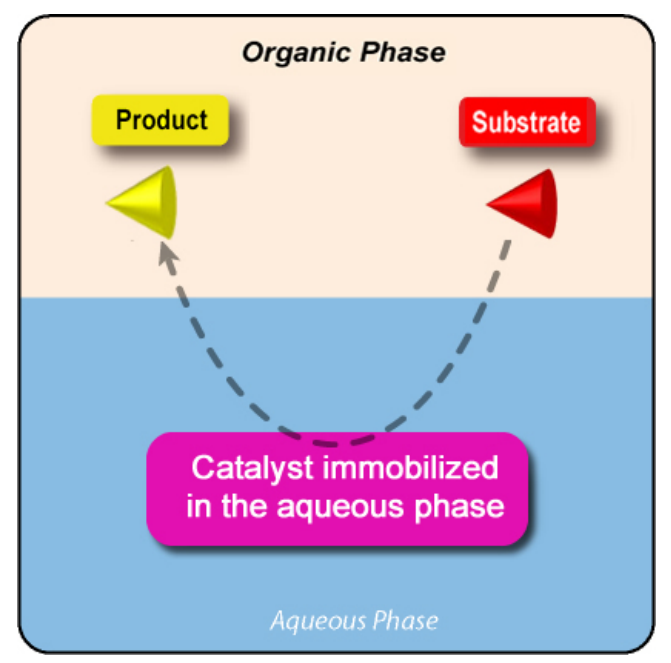

This methodology has proven its viability with the industrial Ruhrchemie/Rhône-Poulenc process (now OXEA company), in which the rhodium catalyzed hydroformylation of propene or butene has been conducted since 1984 producing 800,000 t y ${ }^{-1}$ of $\mathrm{C}_{4}$ and $\mathrm{C}_{5}$ aldehydes. In this process, the rhodium catalyst was efficiently anchored in the aqueous phase via a water-soluble phosphine ligand $\mathrm{P}\left(\mathrm{C}_{6} \mathrm{H}_{4} \mathrm{SO}_{3} \mathrm{Na}\right)_{3}$ (TPPTS), leading to very low metal leaching, i.e., on a ppb scale [6]. However, the scope of aqueous catalysis is greatly reduced by the low solubility of most organic substrates in water and by the need to synthesize water-soluble ligands or stabilizing agents to immobilize the catalyst in water. Indeed, poorly water-soluble substrates react far too slowly under aqueous biphasic conditions for economically viable industrial applications, and the synthesis of water-soluble ligands or stabilizing agents usually requires expensive or non-commercially available reagents, tedious work-up or long multistep reaction sequences [7].

Among the different approaches proposed to circumvent these problems, the use of cyclodextrins (CDs) proves to be very promising [8]. Very concisely, CDs are a class of naturally occurring receptors which are cyclic oligosaccharides constituted of six ( $\alpha-C D)$, seven $(\beta-C D)$, or eight $(\gamma-C D)$ D-glucopyranose units [9]. Their shape is a conical cylinder whose inner surface is hydrophobic and outer surface hydrophilic. The wider opening is surrounded by the whole of the secondary hydroxyl groups, while the narrower opening contains all the primary ones (Figure 2). 
Figure 2. Chemical structure of native cyclodextrins.
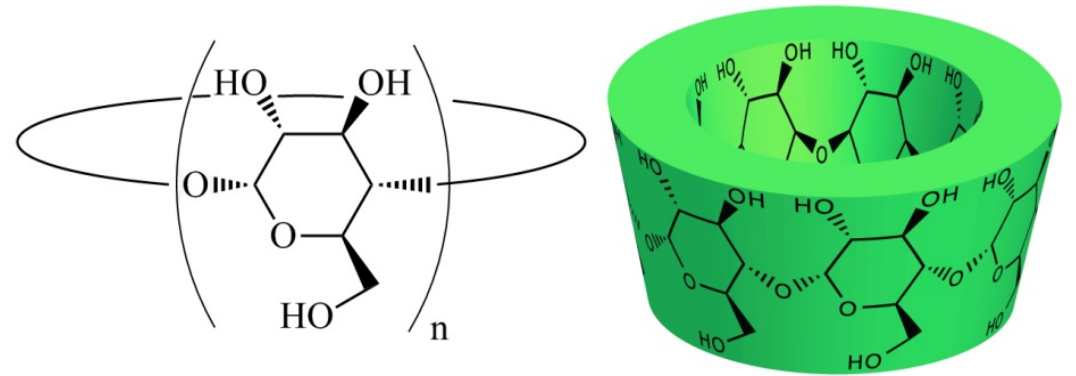

$\mathrm{n}=6 \quad \alpha$-cyclodextrin

$\mathrm{n}=7 \quad \beta$-cyclodextrin

$\mathrm{n}=8 \quad \gamma$-cyclodextrin

The reactivity difference between the primary and secondary hydroxyl groups allows selective functionalization on the primary and secondary rims of CDs. Well-established synthesis protocols for selective modification of CDs have been extensively studied by many researchers and provide the opportunity to fine tune their physicochemical properties (solubility, surface activity, etc.) [10]. Their ability to encapsulate a wide range of guest molecules into their cavity has been widely demonstrated and makes them suitable for applications in analytical chemistry, agriculture, pharmaceutical industry, foodstuffs, toilet articles, textile processing and catalysis [11].

In this review, we will demonstrate that chemically modified CDs allow one to: (i) increase significantly the rate and selectivity of reactions catalyzed by water-soluble organometallic catalysts, (ii) design new water-soluble catalysts, (iii) stabilize catalytically active noble metal nanoparticles in water and (iv) favour the dispersion and activation of palladium on charcoal in water. These outstanding results will be attributed to the complexing and surface active properties of the chemically modified cyclodextrins.

\section{Results and Discussion}

\subsection{Cyclodextrins as Mass Transfer Additives in Aqueous Organometallic Catalysis}

The possibility of using CDs as mass transfer additives in reactions catalyzed by metal transition complexes was independently reported in 1986 by Alper [12] and Takahashi [13]. These authors showed that olefins can be efficiently oxidized to ketones in the presence of oxygen, palladium chloride, copper chloride and native CDs. These pioneering works have led numerous researchers to investigate the effects of native CDs on reaction rates and selectivity. Thus, it has been reported that native CDs were effective mass transfer promoters for the deoxygenation of allylic alcohols [14], and the reduction of $\alpha, \beta$-unsaturated acids [15], $\alpha$-keto esters [16], and conjugated dienes [17]. Another example of a CD-promoted reaction is the reduction of aryl alkyl ketones and aromatic aldehydes to hydrocarbons catalyzed by a dimer of chloro(1,5-hexadiene)-rhodium(I) [18]. Recently, Yorimitsu and Oshima reported that the reaction of benzaldehyde with a trialkylborane having a benzyl ether moiety could be greatly improved by adding native $\beta$-CD into the reaction medium [19]. The authors assumed that $\beta$-CD suppresses an unfavorable interaction between the nickel catalyst and the substrate by including the aromatic ring of substrate into its cavity [20]. However, it should be emphasized that only $\beta$-CD promoted the reaction. Indeed, the yields in the presence of $\alpha$-CD were lower than those observed without CD. Adverse effects of native CDs on transition metal catalyzed reactions have also been reported in two other reactions. The reduction of aldehydes using the ruthenium complex 
[RuCl $2\left(\mathrm{P}_{2}\left(\mathrm{C}_{6} \mathrm{H}_{5}\right)_{2}\left(\mathrm{C}_{6} \mathrm{H}_{4} \mathrm{SO}_{3} \mathrm{Na}\right)\right)_{2}$ ] [21] and the hydroformylation of 1-hexene using the rhodium catalyst $\left[\mathrm{HRh}(\mathrm{CO})\left(\mathrm{P}\left(\mathrm{C}_{6} \mathrm{H}_{5}\right)_{2}\left(\mathrm{C}_{6} \mathrm{H}_{4} \mathrm{SO}_{3} \mathrm{Na}\right)\right)_{3}\right]$ [22] were inhibited by addition of $\beta-\mathrm{CD}$ and $\alpha-\mathrm{CD}$ to the reaction medium, respectively. Although no spectroscopic evidence has been obtained, the detrimental effect of the CD was attributed to interactions between the CD and the catalyst.

A major breakthrough was achieved in 1994 by using chemically modified CDs [23]. Indeed, the chemically modified CDs exhibited a better catalytic activity than native CDs in numerous reactions such as the Wacker oxidation [24-26], hydroxylation of aromatic compounds [27,28], hydrogenation of aldehydes [29,30], Suzuki cross-coupling reaction [31], cleavage of allylic substrates [32], hydroformylation [33-38] or hydrocarboxylation [39,40] of olefins. In the case of the randomly methylated $\beta$-CDs (RAME- $\beta$-CD), it was demonstrated that the catalytic system consisting of metal, water-soluble ligand and RAME- $\beta$-CD could be quantitatively recovered. Indeed, the phase separation between the organic and aqueous phases was fast with this modified CD and no increase in catalyst leaching into the organic phase was observed. In the case of the telomerization of butadiene with glycerol, Behr et al. even reported that RAME- $\beta$-CD reduced the catalyst leaching. So, the amount of palladium catalyst in the organic phase was found to be $70 \mathrm{ppm}$ without mass transfer additive and, only 42 ppm in the presence of RAME- $\beta$-CD [41].

Interestingly, chemically modified CDs can also be used successfully to perform substrate-selective reactions that are difficult to achieve with conventional transition metal catalysts [42]. In fact, when the organic phase contains a mixture of isomers, the water-soluble catalyst reacts with the isomer that preferentially interacts with the CD cavity, inducing substrate selectivity. This type of catalytic system clearly exhibits enzyme-like properties. By using different pairs of structural isomers, it was found that the substrate selectivity strongly depended on the water solubility and the structure of isomers. Thus, high substrate selectivity could only be observed with highly water-insoluble isomers that presented pronounced structural differences. The size-fit concept that postulated the highest reactivity for the best size-matched host-guest pair provided a very useful tool for predicting the values of substrate selectivity $[43,44]$. However, it was noteworthy that the presence of small organic water soluble molecules such as amine or alcohol derivatives appeared to be crucial in the discriminating process. Indeed, the presence of such additives greatly enhanced the substrate selectivity. For instance, the addition of triethylamine to the reaction medium improved the discriminating power of RAME- $\beta$-CD by a factor of 7 . These unexpected results were explained by considering the formation of ternary $\mathrm{CD} /$ substrate/additive complexes [45].

The precise role of chemically modified CDs was established by a careful analysis of experimental data (surface tension and association constant measurements) [46,47] and molecular dynamics simulations $[48,49]$. It is now well established that chemically modified CDs favour the contact between the organometallic catalyst and the substrate at the interface or into the bulk aqueous phase according to the nature of the substrate. In fact, when a mechanism of inverse phase catalysis is proposed for partially water-soluble substrates (Figure 3a), the reaction of highly water-insoluble substrates is believed to occur by an interfacial catalysis mechanism (Figure 3b). 
Figure 3. Principle of aqueous biphasic organometallic catalysis mediated by modified CDs.
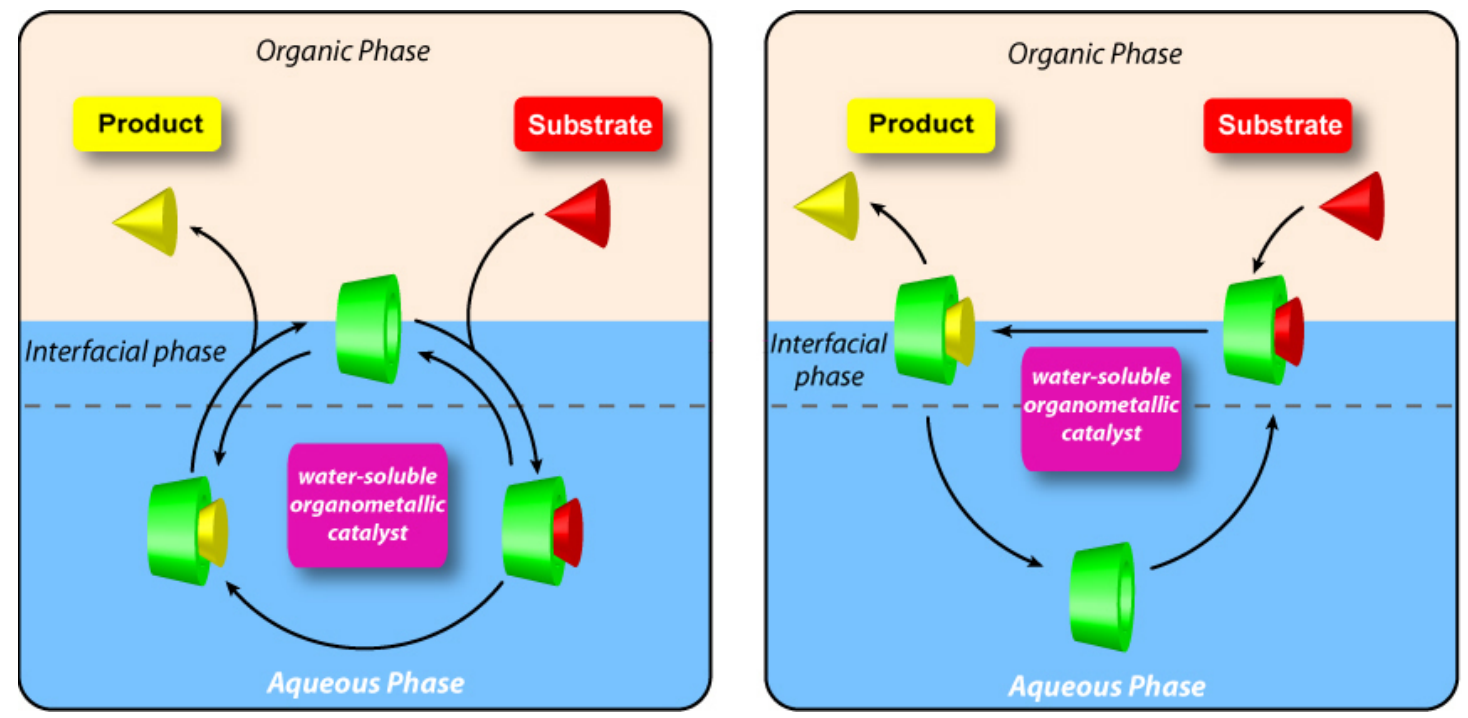

(a) Inverse phase transfer catalysis (b) Interfacial catalysis

Finally, it is worthwhile to point out that a catalytic amount of modified CDs is sufficient to observe a positive effect on the reaction rate and selectivity. Indeed, a substrate or product inhibition is a phenomenon rarely observed with the modified CDs. However, a stoechimetric amount of CD relative to the substrate can also be used. For instance, Deng and Yang reported that hydroxypropyl $\beta$-CD/acetylene derivatives inclusion complexes could be successfully polymerized in aqueous solution by using a water-soluble Rh-based catalyst, [Rh(cod $\left.)_{2} \mathrm{BF}_{4}\right]$ or $\left[\mathrm{Rh}(\mathrm{nbd})\left(\mathrm{H}_{2} \mathrm{O}\right) \mathrm{OTs}\right]$. The polymers could be obtained in very high yields and exhibited little difference to their counterparts obtained via copolymerization in organic solvents [50].

In these works, it was evidenced that $\beta$-CD and RAME- $\beta$-CD could interact with the monosulfonated triphenylphosphine (TPPMS) and the trisulfonated triphenylphosphine (TPPTS), two water-soluble ligands widely used in aqueous organometallic catalysis [51-56]. For instance, titration and continuous variation plots obtained from ${ }^{31} \mathrm{P}$ - and ${ }^{1} \mathrm{H}-\mathrm{NMR}$ data proved the formation of a $1: 1$ inclusion complex between $\beta$-CD and TPPTS. T-ROESY NMR experiments showed that a sulfonated aromatic ring was included into the hydrophobic cavity of $\beta$-CD from the secondary hydroxyl groups side (Figure 4).

Figure 4. Side view and top view of $\beta$-CD/TPPTS inclusion complex.
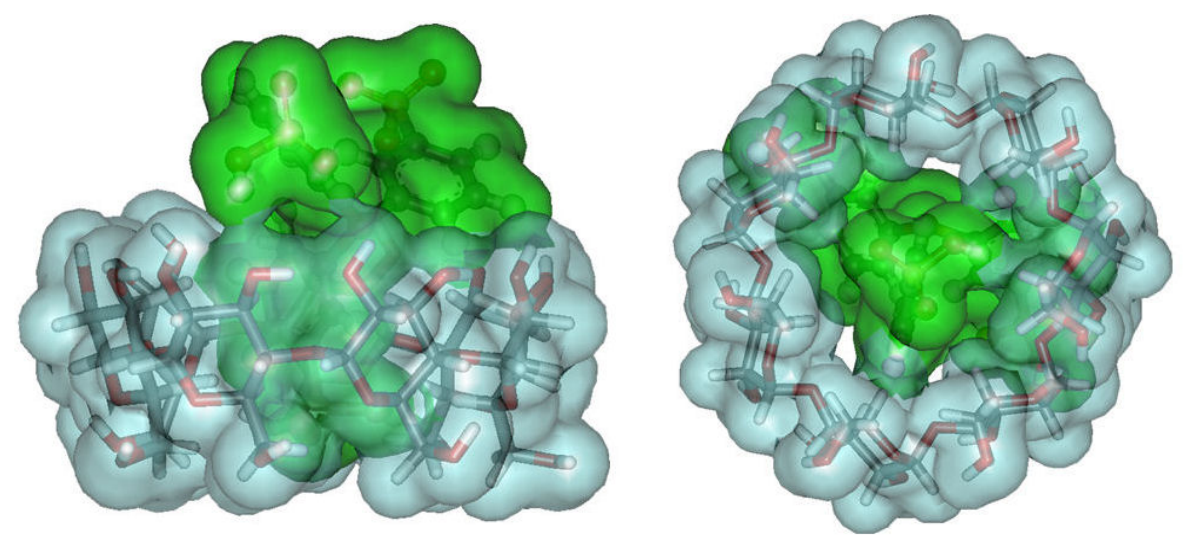
Formation of such inclusion complexes induced in some cases a decrease in the activity and selectivity [57] or a modification of the catalyst structure [58]. However, the interaction between $\beta$-CD and TPPTS could be avoided by using properly modified $\beta$-CDs. Thus, introduction of sulfobutyl ether groups on the secondary face of $\beta$-CD impeded the formation of inclusion complex by electronic repulsion between the anionic groups of the $C D$ and the sulfonate groups of the water-soluble phosphine [59]. A full methylation of the $\beta$-CD secondary face was also an efficient solution to impede inclusion by greatly reducing the accessibility to the cavity [60,61].

The behavior of native $\beta$-CD or RAME- $\beta$-CD towards other water-soluble phosphines has also been explored [62-66]. For instance, bulky water-soluble monodentate phosphines such as TPPTS bearing a methyl group in the ortho position on each aromatic ring [62] or 1,3,5-triaza-7-phosphaadamantane derivatives [63] have been considered as non-interacting phosphines as no alteration of the catalytic performances was detected with these phosphines in the presence of RAME- $\beta$-CD. The affinity of bidentate phosphines for $\beta$-CD or RAME- $\beta$-CD was found to be dependent on the nature of the linker between the phosphorous atoms. Thus, sulfonated (diphenylphosphino)alkane such as tetrasulfonated 1,4-bis(diphenylphosphino)butane [64] interacted more strongly with $\beta$-CDs than sulfoxantphos [65]. The difference of affinity was attributed to the great flexibility of the alkyl chain compared to the xanthene skeleton. Interestingly, in the case of the sulfoxantphos ligand, the catalytic results showed that, concurrently to the constraint generated by the bulky sulfonated xantphos ligand, the additional steric stress of the CD cavity on the substrate compelled the latter to react preferentially by its terminal carbon, leading to very high regioselectivity towards linear aldehyde (Figure 5) [65].

Figure 5. Hydroformylation of 1-decene catalyzed by rhodium/Sulfoxantphos system in the presence of RAME- $\beta$-CD.
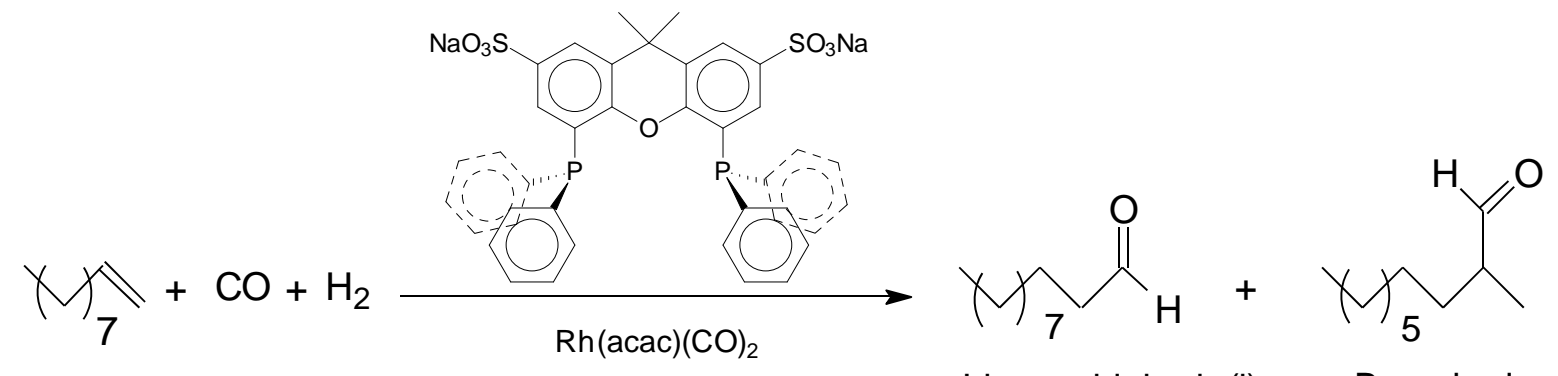

Linear aldehyde (I)

Branched aldehyde (b)
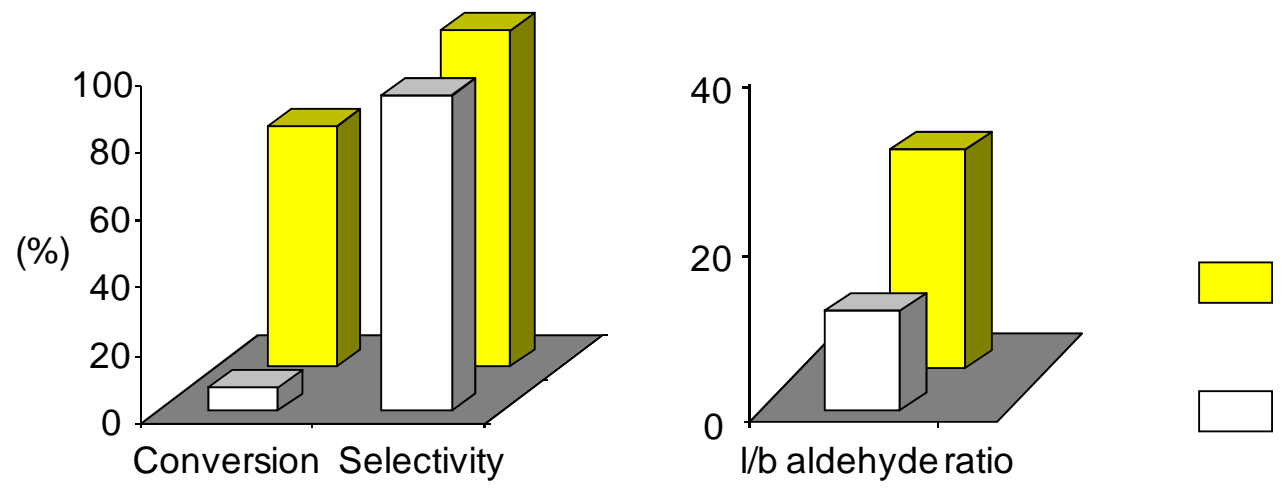

RAME- $\beta-C D$

Without cyclodextrin 
Contrary to $\beta$-CDs, it has been reported that $\alpha$-CDs cannot interact with TPPTS $[57,67]$. Indeed, these $\alpha$-CDs have smaller cavities, which prohibit the inclusion processes of the phosphine aromatic cycles inside the CD cavities. Moreover, grafting an alkylammonium chain on a $\alpha$-CD resulted in new catalytic supramolecular species, where CD behaved both as a transient ligand and as a supramolecular shuttle that can bring the substrate to the water-soluble organometallic catalyst (Figure 6) [68].

Figure 6. Transient formation of organometallic complexes in the presence of a $\alpha$-CD modified by an alkylammonium chain. $\mathbf{S}$ represents a substrate included into the CD cavity.

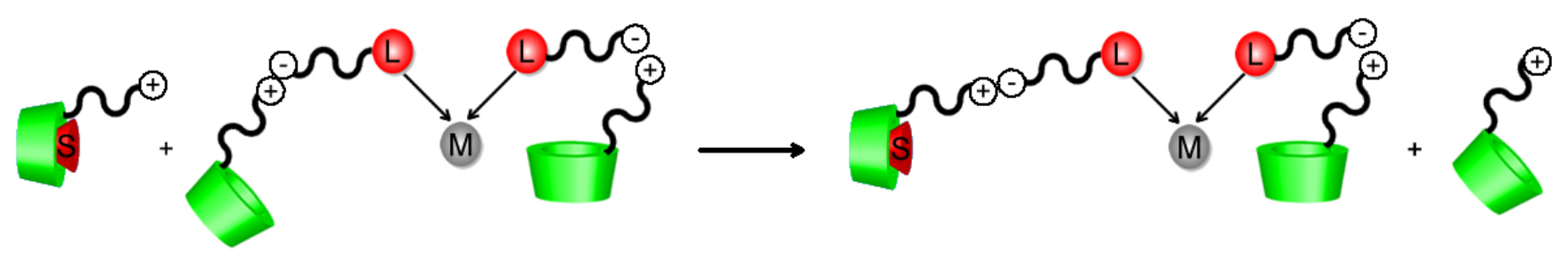

\subsection{New Water-Soluble Catalysts Based on Cyclodextrins}

The ability of chemically modified CDs to interact with phosphines can be used to generate water-soluble phosphine low-coordinated organometallic complexes that are generally accepted as the catalytically active species in numerous transition-metal-catalysed reactions [69,70]. The strategy relied on the ability of RAME- $\beta$-CD to interact strongly with tert-butylphenyl group of phosphine $\mathbf{1}$ (Figure 7).

Figure 7. Phosphine used to generate phosphine low-coordinated organometallic complexes.

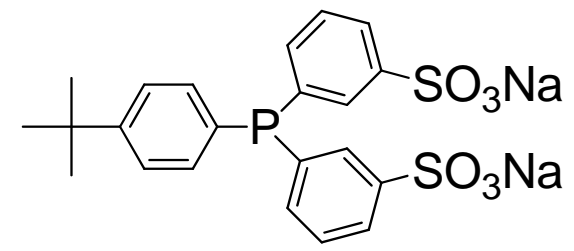

As a consequence of this strong interaction ( $\left.\mathrm{K}_{\mathrm{RAME}-\beta-\mathrm{CD} / \mathbf{1}}: 250,000 \mathrm{M}^{-1}\right)$, RAME- $\beta$-CD could induce a shift of the equilibrium towards the phosphine low-coordinated complexes $M(1)_{n-1}$ by trapping the free phosphine 1 (pathway A in Figure 8) and/or binding to an organometallic complex $\mathrm{M}(\mathbf{1})_{\mathrm{n}}$ (pathway B in Figure 8). In this last case, the local bulkiness around the metallic centre of the obtained supramolecular adducts become too high and a steric decongestion by dissociation of the RAME- $\beta$-CD/phosphine inclusion complex from the metal occurs, leading to phosphine lowcoordinated complexes as schematically represented in Figure 8. 
Figure 8. Mechanisms postulated for the generation of phosphine low-coordinated organometallic complexes.

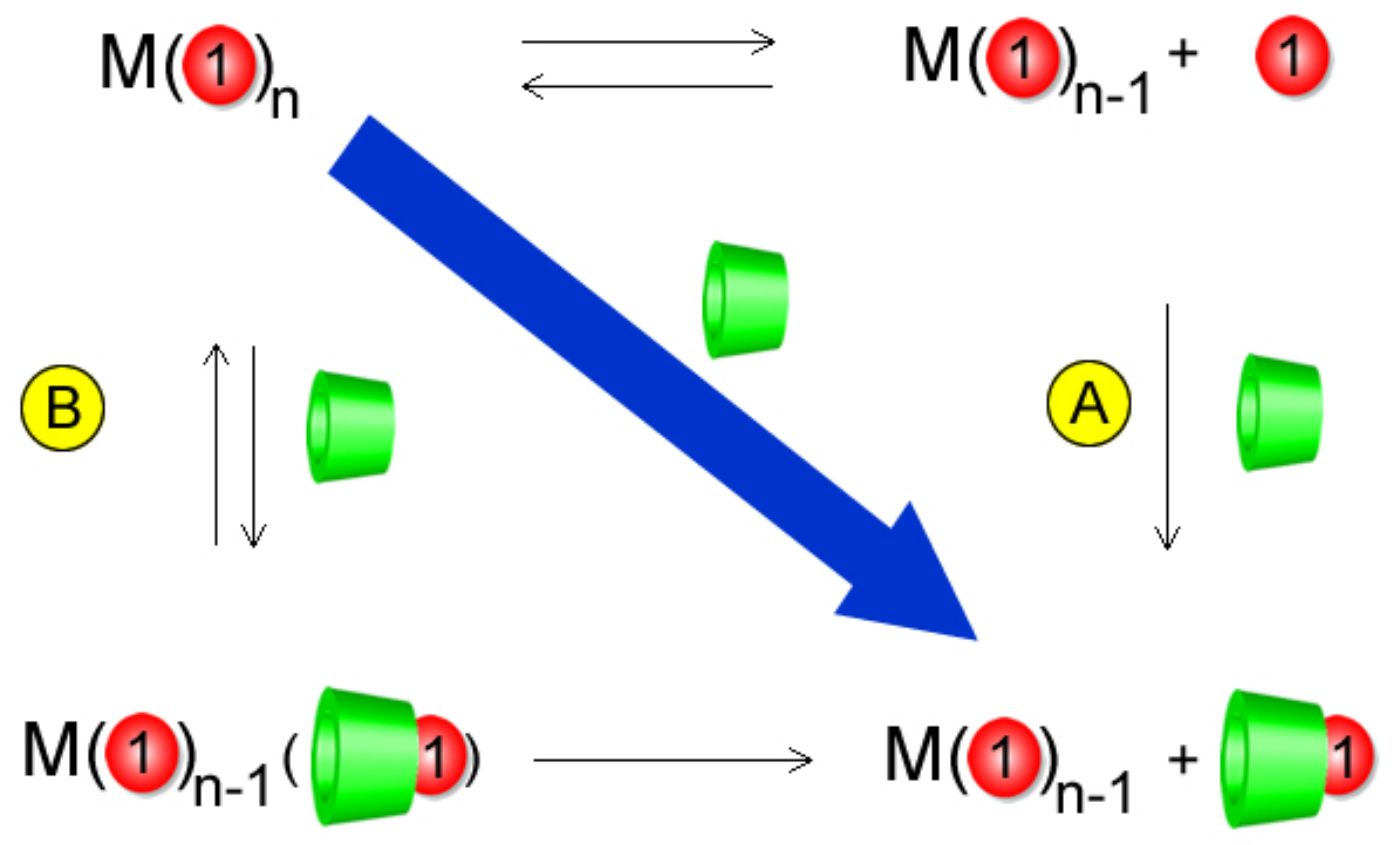

The ability of phosphine $\mathbf{1}$ to form very stable inclusion complexes with chemically modified CDs has also been used to design water-soluble supramolecular bidentate ligand for aqueous organometallic catalysis [71]. Thus, the inclusion of phosphine 1 into the cavity of $6^{\mathrm{I}}$-amino- $6^{\mathrm{I}}$-deoxycyclomaltoheptaose by the $\mathrm{NH}_{2}$-containing face resulted in the formation of a rigid chelating bidentate ligand, with the nitrogen and the phosphorus atoms on the same side of the supramolecular edifice. This self-assembled bidentate ligand could coordinate platinum complexes to efficiently catalyze the hydrogenation of a water-soluble allylic alcohol (Figure 9).

Figure 9. Platinum-catalyzed hydrogenation of 2-methyl-3-buten-2-ol in water.

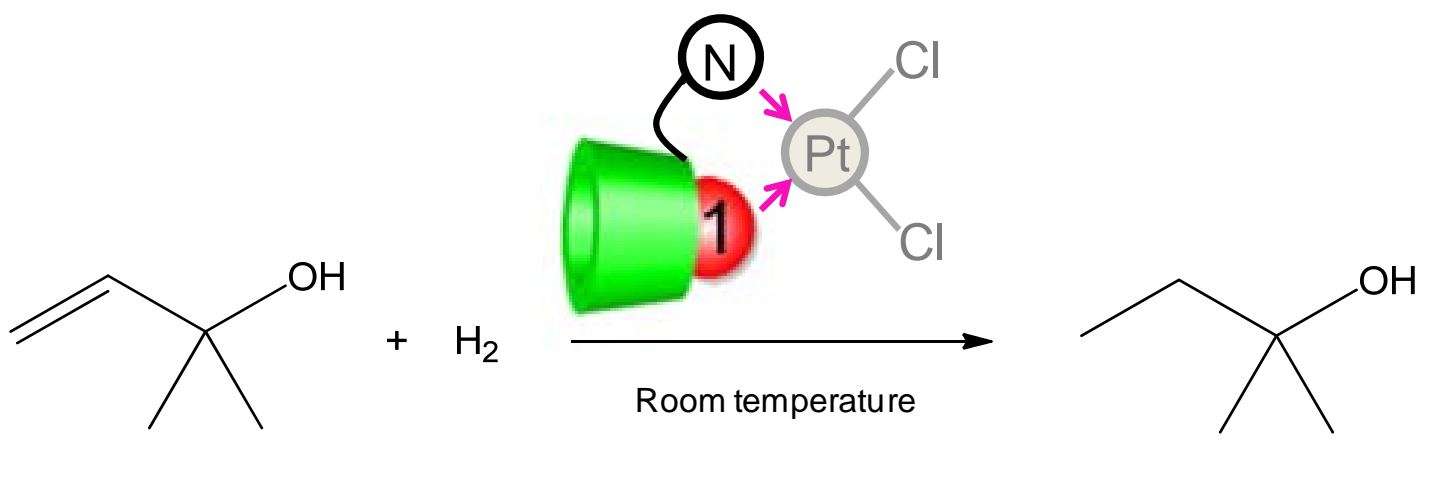

Initial activity: $2600 \mathrm{~h}^{-1}$

In contrast to phosphine 1, phosphine $\mathbf{2}$ allowed the formation of stable second-sphere coordination adducts (Figure 10). In this case, RAME- $\beta$-CD could bind to the metal coordinated phosphine without inducing dissociation of the phosphine because CD remained far from the coordinated phosphorus 
atom. Interestingly, these second sphere coordination adducts derived from $\mathbf{2}$ were active in Trost-Tsuji reaction [72].

Figure 10. Phosphine used to generate stable second-sphere coordination adducts.

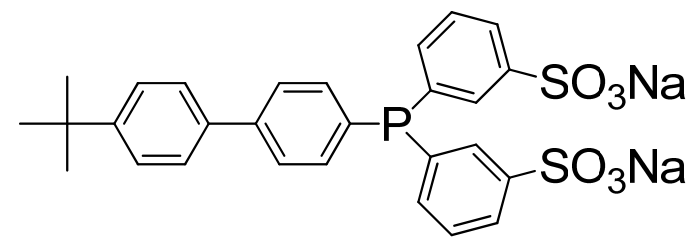

2

Interestingly, more sophisticated approaches involving the covalent attachment of catalyst to CD through a spacer have also been performed to combine molecular recognition, phase transfer property and metal catalysis. In this case, modified CDs may be regarded as enzyme mimics. Indeed, these catalysts generally show substrate specificity for molecules that can bind into the CD cavity and are highly selective, including stereospecificity. One of the pioneers in this field is Breslow [73]. Indeed, he reported as far back as 1970 that the compound displayed in Figure 11 could efficiently catalyze the hydrolysis of substrates that could bind into the CD cavity and that were not normally hydrolyzed by copper complexes without the CD binding component [74].

Figure 11. First CD modified by a metal-binding group.

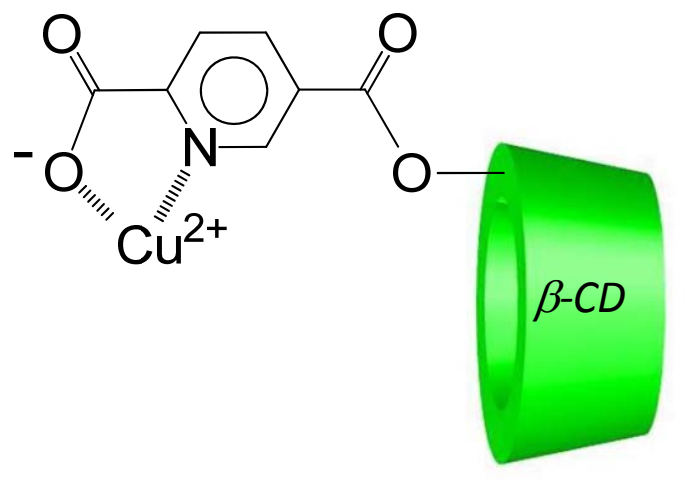

Since this seminal work, many research groups have attached catalytically active centers to $\beta$-CD and have used them to perform oxidation-reduction reactions or hydrolysis of esters and phosphates [75-79]. Surprisingly, the possibility to use modified CDs as ligands in reactions catalyzed by traditional transition metals such as $\mathrm{Rh}$, Pd or Ru has hardly been investigated [80,90]. This is all the more surprising that these transition metals are involved in important aqueous biphasic reactions as hydrogenation, hydroformylation or the Wacker oxidation. The first significant work in this field was reported by Reetz in 1997. The author achieved the synthesis of various $\beta$-CD-based diphosphines and successfully used them as ligands in hydrogenation and hydroformylation reactions [80-83] (Figure 12). 
Figure 12. CD based diphosphines for aqueous organometallic catalysis.
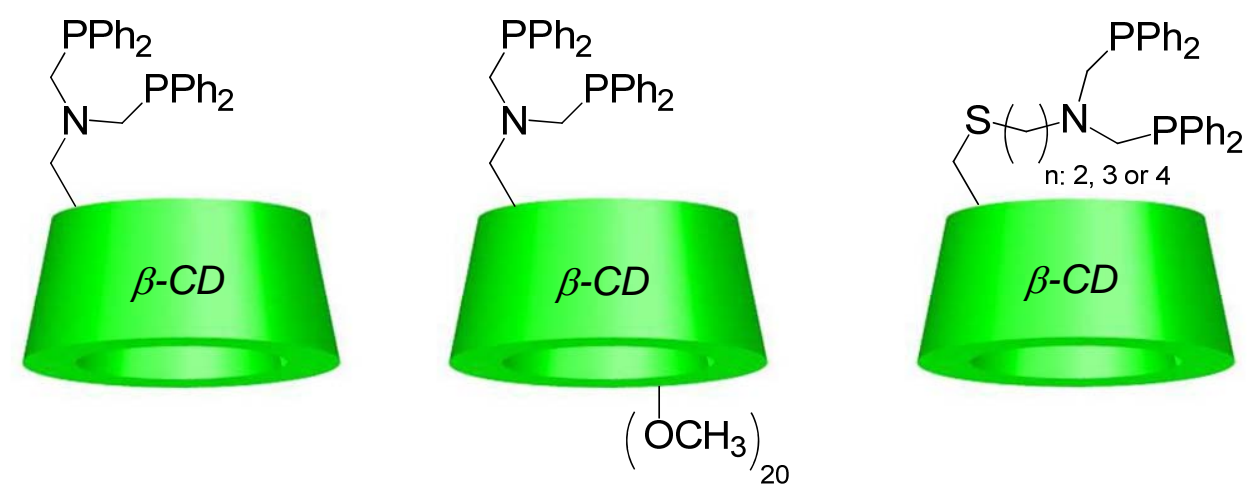

Unfortunately, the author reported that the catalytic systems cannot be recovered quantitatively due to partial transfer of the catalyst into the organic phase [82]. Water-soluble palladium complexes based on nitrile-modified $\beta$-CD were also reported to be very active and can serve as selective catalysts for the Wacker oxidation of 1-alkenes in a two-phase system [86]. The high catalytic activities of these catalysts were explained by a simultaneous interaction of alkene with both the CD cavity and the palladium ion attached to the CD [87]. The catalyst efficiency was also affected by the position of the palladium ion with respect to the cavity of the macrocyclic receptor. For example, the activity of the palladium complex in which the nitrile group was attached to the CD secondary face significantly differed from the activity of the complex in which the palladium ion was bound to the complexing group attached to CD primary face $[26,88]$. Woggon reported a similar phenomenon during the enantioselective hydrogenation of ketones catalyzed by ruthenium complexes linked to $\beta$-CD [89,90]. Thus, ruthenium- $\eta$-arene complexes attached to the secondary face of $\beta$-CD catalyzed more efficiently the enantioselective reduction of ketones in the presence of sodium formate than ruthenium- $\eta$-arene complexes attached to the primary face. Enantioselectivities from $70 \%$ to $98 \%$ were observed for a series of aliphatic and aromatic ketones, representing the highest ee values for these challenging substrates to date and also showing unprecedentedly high enantioselectivity of a catalyst in which $\beta$-CD was the only chiral auxiliary.

\subsection{Water-Soluble Catalytically Active Metallic Nanoparticles Stabilized by Cyclodextrins}

The first example of metallic nanoparticles stabilized by native CDs was reported by Komiyana et al. in 1983 [91]. These authors reported that refluxing an aqueous solution of rhodium (III) and $\alpha-C D$ or $\beta-C D$, followed by further refluxing in the presence of ethanol gave a colloidal dispersion of rhodium particles of $28 \AA$ in diameter. Interestingly, this colloidal dispersion effectively catalyzed the hydrogenation of various olefins such as acrylonitrile, 3-buten-2-one and 3,4-dimethyl-3penten-2-one at $30{ }^{\circ} \mathrm{C}$ under atmospheric pressure. The ability of native $\beta$-CD to stabilize metallic nanoparticles was also observed by Willner et al. in 1987 [92]. These authors showed that heterogeneous Pd colloids stabilized by $\beta$-CD catalyzed the photoreduction of bicarbonate to formate. Furthermore, the $\mathrm{Pd} / \beta-\mathrm{CD}$ colloids acted as artificial enzymes. For example, the catalytic system exhibited high specificity and effectiveness towards $\mathrm{CO}_{2} / \mathrm{HCO}_{3}{ }^{-}$reduction and was competitively inhibited towards the substrate activation and reduction [93]. Recently, Qi et al. reported the controlled synthesis of Au nanoparticles with adjustable sizes and narrow size distributions by directly reducing 
hydrochloroauric acid with $\alpha$-CD in an alkaline aqueous solution. The obtained $\alpha$-CD capped Au nanoparticles exhibited good catalytic activities for the reduction of 4-nitrophenol in the presence of $\mathrm{NaBH}_{4}$ [94]. The reaction rate constant was inversely proportional to the nanoparticles diameter, suggesting that the catalysis takes place on the nanoparticles surface.

The synthesis of metallic nanoparticles stabilized by chemically modified CDs has also been investigated. Kaifer et al. reported that per-6-thio- $\beta$-CD effectively stabilized Pd or Pt nanoparticles without passivating their surface [95]. FTIR spectra indicated that per-6-thio- $\beta$-CD was chemisorbed on the surface of the metal nanoparticles as the weak S-H stretching peak, which was clearly visible in the spectrum of free CD, disappeared in the spectrum of the nanoparticles. Interestingly, it was found that these modified CDs were effective catalysts for the hydrogenation of $\mathrm{C}=\mathrm{C}$ or $\mathrm{C}=\mathrm{N}$ double bonds [96,97] and for C-C coupling reactions such as the Suzuki [98] and Sonogashira [99] reactions. In these works, it was also demonstrated that the catalytic activity of the nanoparticles could be modulated by host-guest interactions between the surface immobilized CDs and properly chosen hosts. Finally, the authors mentioned that the solubility mismatch between the highly hydrophilic per-6-thio$\beta$-CD capped metallic nanoparticles and the hydrophobic reactants tended to limit the applications of this type of CD capped metallic nanoparticles.

The low affinity of CD capped nanoparticles for hydrophobic substrates could be solved by using randomly methylated CDs (RAMECDs) [100]. Contrary to native or perthiolated CDs, the methylated CDs could not only stabilize the metallic nanoparticles but also facilitate the mass transfer between the organic phase and the catalyst-containing phase (Figure 13).

Figure 13. Methylated CDs as protective agents and mass transfer additives in metallic nanoparticles catalyzed reactions.

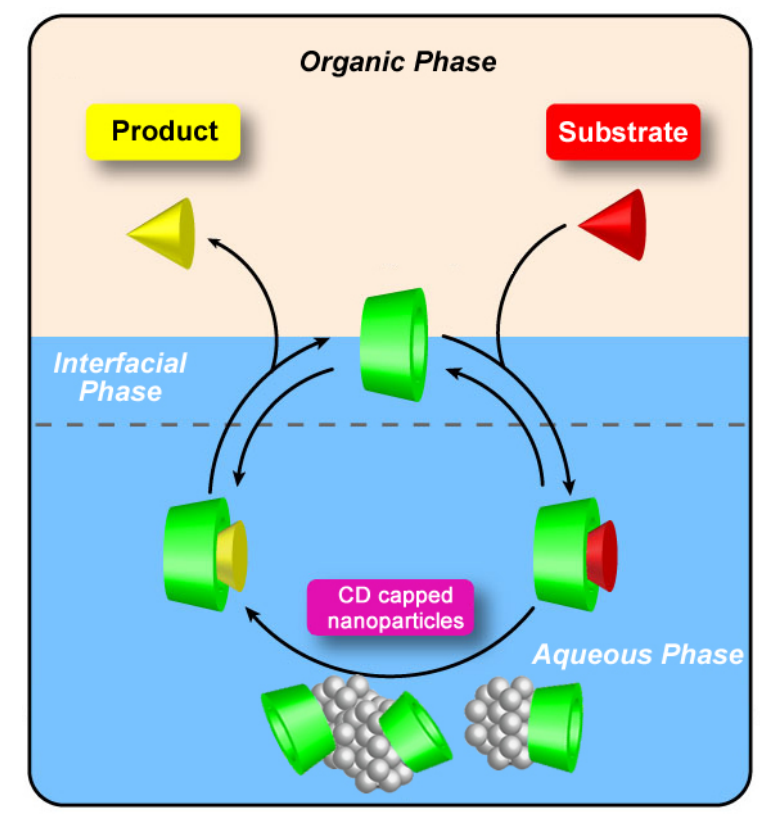

Indeed, RAMECDs are weakly adsorbed on metal surface and their mass transfer ability remains high. Consequently, the RAMECDs-capped $\mathrm{Ru}(0)$ nanoparticles proved to be very active in the hydrogenation of olefins such as $\alpha$ - or $\beta$-pinene, and more particularly, of aromatic compounds under biphasic conditions at room temperature and atmospheric hydrogen pressure [101]. Moreover, 
interesting chemoselectivity has been observed in the hydrogenation of monofunctionalised arene derivatives according to the relevant choice of cavity and methylation degree of the CD. Interestingly, these nanocatalysts could be easily reused without a significant loss of catalytic activity.

Hydrogenation of arene derivatives has also been successfully performed in water by using $\mathrm{Ru}(0)$ nanoparticles stabilized by 1:1 inclusion complexes formed between RAME- $\beta$-CD and an ammonium salt bearing a long alkyl chain [102]. These nanoparticles stabilized by a CD inclusion appeared more active than the nanoparticles stabilized by classical surfactants. The origin of this better efficiency was attributed to a dynamic organization of the protective agents around the nanoparticles. Indeed, it was assumed that the polar head of the surfactant was directed towards the metallic surface and that RAME- $\beta$-CD interacting with the alkyl chain of the surfactant could be partially released into the bulk aqueous phase as schematically shown in Figure 14.

Figure 14. Dynamic organisation of the stabilizers around the $\mathrm{Ru}(0)$ nanoparticles.

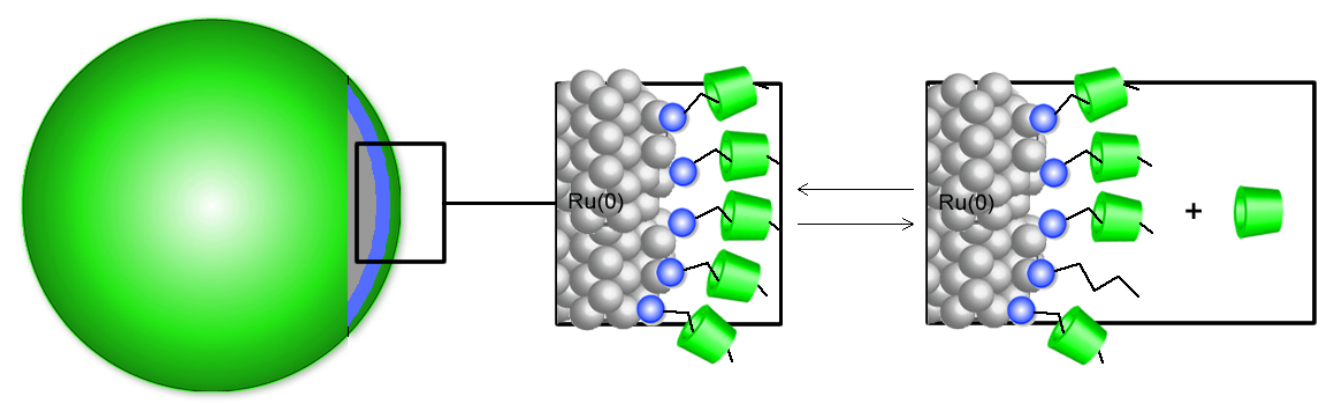

Moreover, it was also postulated that RAME- $\beta$-CD could exert some control on the surfactant adsorption process, acting as a suitable spacer between the alkyl chains of the surfactants, reducing their intermolecular interactions and consequently allowing a better diffusion of substrates towards the metallic surface.

\subsection{Dispersion and Activation of Palladium Charcoal by Cyclodextrins}

Fornasier et al. first reported the use of CD and palladium on charcoal in 1987 [103]. They examined the hydrogenation of acetyl and benzoyl-substituted pyridines in the presence of native $\beta$-CD in aqueous solution, and results indicated that native $\beta$-CD had a rather modest effect on the reaction. In fact, the experimental data suggested that the effect exerted by native $\beta$-CD in this reaction could be merely a type of solvent effect. More positive results were reported by Shimizu et al. in 1990 [104]. Indeed, these authors showed that native CDs functioned as inverse phase transfer catalysts for the reduction of aryl bromides with sodium formate in the presence of a charcoal-supported palladium catalyst. The efficiency of the CDs was found to be dependent on the CD size and the best results were obtained with $\beta$-CD. It was also concluded that the inclusion complex formed between the $\mathrm{CD}$ and substrate did not interact with the palladium catalyst, and that most of the reaction was probably carried out by the free species.

Recently, chemically modified CDs have also been used in reactions such as the hydrodechlorination of $\mathrm{CCl}_{4}$ [105], the Suzuki-Miyaura reaction [106] and the Heck reaction [107]. The modified CDs, particularly RAMECDs, appeared much more efficient than native CDs to increase the reaction rates and selectivities. The high efficiency of RAMECDs was attributed to a combination 
of several effects: a well-known mass transfer effect but also a dispersing and activation effect of methylated CDs (Figure 15).

Figure 15. Multiple role of methylated CDs in aqueous biphasic Pd/C catalyzed reactions.

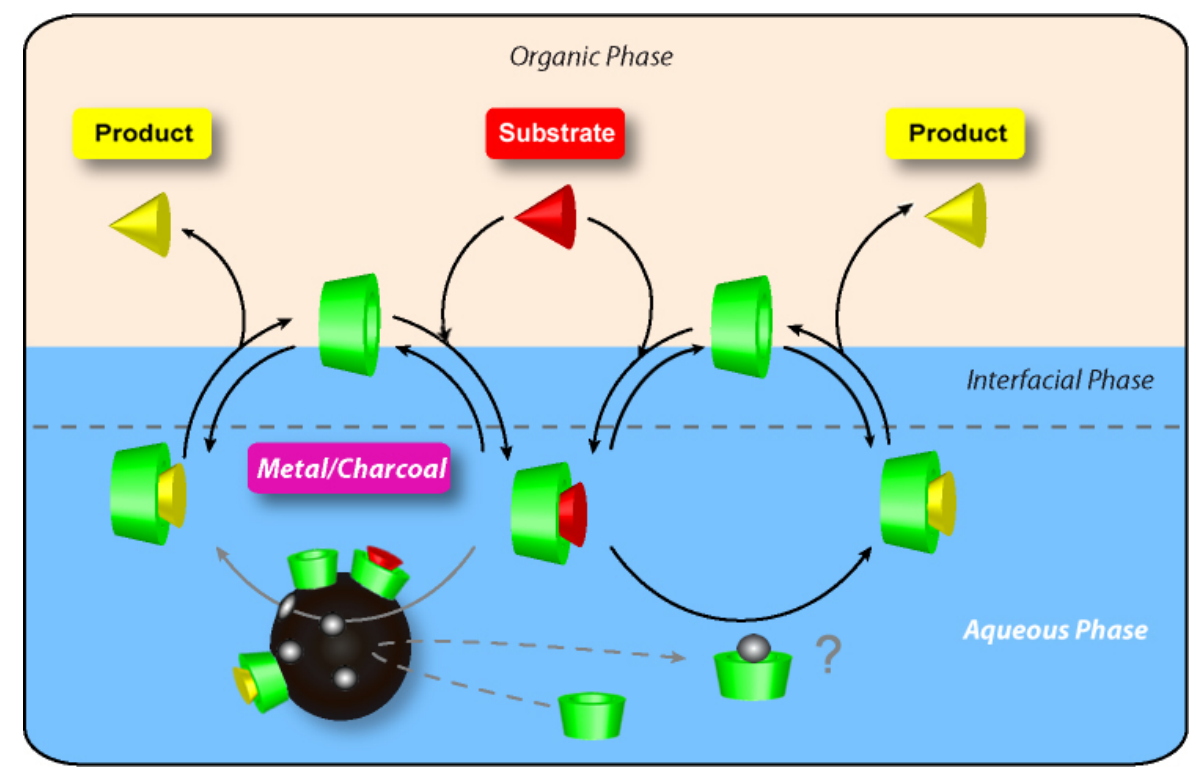

Beneficial effect of methylated CDs on the dispersion of the $\mathrm{Pd} / \mathrm{C}$ catalyst in water was easily demonstrated by observing the distribution of $\mathrm{Pd} / \mathrm{C}$ in a two-phase system (Figure 16). Indeed, a much more homogeneous distribution of the $\mathrm{Pd} / \mathrm{C}$ catalyst in the aqueous phase was obtained with the RAME- $\beta$-CD, compared with native $\beta$-CD. The dispersion of $\mathrm{Pd} / \mathrm{C}$ in water in the presence of CD was attributed to the adsorption of $\mathrm{CD}$ on the surface of the $\mathrm{Pd} / \mathrm{C}$ catalyst. Indeed, adsorption of $\mathrm{CD}$ increased the hydrophilic character of the support, making its dispersion in the aqueous phase easier.

Figure 16. $\mathrm{Pd} / \mathrm{C}$ distribution in a mixture of water/heptane $(10 \mathrm{mg} / 10 \mathrm{~mL} / 10 \mathrm{~mL})$ : (a) without CD; (b) with $57 \mathrm{mg}$ of native $\beta$-CD (0.05 mmol); (c) with $66 \mathrm{mg}$ of RAME- $\beta$-CD (0.05 mmol).

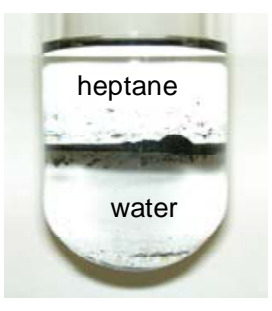

(a) Without CD

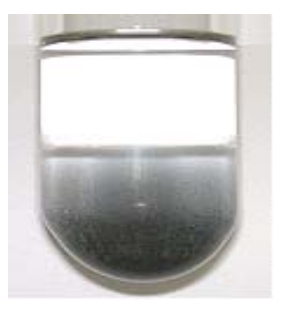

(b) $\beta-C D$

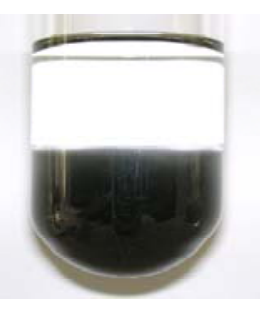

(c)RAME- $\beta$-CD

The activation effect of methylated CDs was confirmed by elemental analyses of aqueous and organic phases [108]. Elemental analyses of the organic phases showed that RAMECDs did not notably increase palladium leaching in the solution. Indeed, the amount of palladium in the organic phase in the presence of RAMECDs was identical to that of without CD, which confirmed the recyclability of the catalytic system. However, it was found that the amount of Pd in the aqueous phase was higher in the presence of RAMECDs. The nature and the role of this solubilized palladium species 
have not yet been elucidated. It must be pointed out that a similar phenomenon has also been described by Antunes et al. in Heck reactions catalyzed by $\mathrm{Pd} / \mathrm{BaCO}_{3}$ and hydroxylpropylated $\mathrm{CD}$. It was assumed that hydroxylpropylated $\mathrm{CD}$ increased the dispersion of the $\mathrm{Pd} / \mathrm{BaCO}_{3}$ and stabilized $\mathrm{Pd}$ clusters leached from the support. In fact, the heterogeneous $\mathrm{Pd} / \mathrm{BaCO}_{3}$ solid could act as a reservoir of catalytically active Pd species [109,110].

\section{Conclusions}

This review highlights that chemically modified CDs are very attractive compounds to develop catalytic processes in aqueous media. Indeed, a wide range of catalytic reactions including hydrogenation, hydroformylation, oxidation, reduction and carbon-carbon coupling reactions have been successfully achieved in this environmentally friendly medium thanks to these cheap and bulk commercially-available compounds. The possibility of performing substrate-selective reactions as enzymes offers a further dimension to CD-based catalysis. In the future, chemically modified CDs may also give the opportunity to promote reactions in other green solvents such as ionic liquids [111] or supercritical carbon dioxide [112-115].

\section{Acknowledgements}

This work was supported by the Ministère de l'Enseignement Supérieur et de la Recherche, the Centre National de la Recherche Scientifique (CNRS), the Institut de Recherche en ENvironnement Industriel (IRENI) and the Agence Nationale de la Recherche (ANR). Roquette Frères (Lestrem, France) is gratefully acknowledged for generous gifts of cyclodextrins. The authors are grateful to G. Crowyn for his technical contribution.

\section{References and Notes}

1. Shaughnessy, K.H. Hydrophilic ligands and their application in aqueous-phase metal-catalyzed reactions. Chem. Rev. 2009, 109, 643-710.

2. Liu, S.; Xiao J. Toward green catalytic synthesis-Transition metal-catalyzed reactions in nonconventional media. J. Mol. Catal. A: Chem. 2007, 270, 1-43.

3. Schulz, J.; Roucoux A.; Patin, H. Unprecedented efficient hydrogenation of arenes in biphasic liquid-liquid catalysis by re-usable aqueous colloidal suspensions of rhodium. Chem. Commun. 1999, 535-536.

4. Hubert, C.; Denicourt-Nowicki, A.; Guégan, J.P.; Roucoux, A. Polyhydroxylated ammonium chloride salt: a new efficient surfactant for nanoparticles stabilisation in aqueous media. Characterization and application in catalysis. J. Chem Soc. Dalton Trans. 2009, 36, 7356-7358.

5. Nowicki, A.; Le Boulaire, V.; Roucoux, A. Nanoheterogeneous catalytic hydrogenation of arenes: Evaluation of the surfactant-stabilized aqueous ruthenium(0) colloidal suspension. Adv. Synth. Catal. 2007, 349, 2326-2330.

6. Cornils, B. Industrial aqueous biphasic catalysis: Status and directions. Org. Process Res. Dev. 1998, 2, 121-127. 
7. Cole-Hamilton, D.J.; Tooze, R.P. Catalyst Separation, Recovery and Recycling: Chemistry and Process Design; Series: Catalysis by Metal Complexes; Springer: Dordrecht, The Netherlands, 2006.

8. Monflier, E.; Komiyama, M. Cyclodextrins and Catalysis. In Cyclodextrins and Their Complexes: Chemistry, Analytical Methods, Applications; Dodziuk, H., Ed.; Wiley-VCH: Weinheim, Germany, 2006; pp. 93-105.

9. Szejtli, J. Introduction and general overview of cyclodextrin chemistry. Chem. Rev. 1998, 98, 1743-1753.

10. Khan, A.R.; Forgo, P.; Stine, K.J.; D’Souza, V.T. Methods for selective modifications of cyclodextrins. Chem. Rev. 1998, 98, 1977-1996.

11. Martin del Valle, E.M. Cyclodextrins and their uses: a review. Process Biochem. 2004, 39, 1033-1046.

12. Zahalka, H.A.; Januszkiewicz, K.; Alper, H. Olefin oxidation catalyzed by palladium chloride using cyclodextrins as phase transfer agents. J. Mol. Catal. 1986, 35, 249-253.

13. Harada, A.; Hu, Y.; Takahashi, S. Cyclodextrin-palladium choride. New catalytic system for selective oxidation of olefins to ketones. Chem. Lett. 1986, 15, 2083-2084.

14. Lee, J.T.; Alper, H. The hydridopentacyanocobaltate anion induced deoxygenation of allylic alcohols using $\beta$-cyclodextrin as a phase transfer agent. Tetrahedron Lett. 1990, 31, 4101-4104.

15. Lee, J.T.; Alper, H. $\beta$-cyclodextrin and hydridopentacyanocobaltate catalyzed selective hydrogenation of $\alpha, \beta$-unsaturated acids and their derivatives. Tetrahedron Lett. 1990, 31, 1941-1942.

16. Pinel, C.; Gendreau-Diaz, N.; Bréhéret, A.; Lemaire, M. Asymmetric hydrogenation of $\alpha$-keto ester with diamine-complex metal. J. Mol. Catal. A: Chem. 1996, 112, L157-L161.

17. Lee, J.T.; Alper, H. Regioselective hydrogenation of conjugated dienes catalyzed by hydridopentacyanocobaltate anion using $\beta$-cyclodextrin as the phase transfer agent and lanthanide halides as promoters. J. Org. Chem. 1990, 55, 1854-1856.

18. Zahalka, H.; Alper, H. $\beta$-cyclodextrin-promoted, rhodium(I)-catalyzed conversion of carbonyl compounds to hydrocarbons under remarkably mild conditions. Organometallics 1986, 5, 1909-1911.

19. Hirano, K.; Yorimitsu, H.; Oshima, K. Alkylation of aldehydes with trialkylboranes in water. Adv. Synth. Catal. 2006, 348, 1543-1546.

20. Hirano, K.; Yorimitsu, H.; Oshima, K. Nickel-catalysed reactions with trialkylboranes and silacyclobutanes. Chem. Commun. 2008, 28, 3234-3241.

21. Benyei, A.; Joo, F. Organometallic catalysis in aqueous solutions: The biphasic transfer hydrogenation of aldehydes catalyzed by water-soluble phosphine complexes of ruthenium, rhodium and iridium. J. Mol. Catal. 1990, 58, 151-163.

22. Anderson, J.R.; Campi, E.M.; Jackson, W.R. Hydroformylation of olefins with water-soluble rhodium catalysts in the presence of $\alpha$-cyclodextrin. Catal. Lett. 1991, 9, 55-58.

23. Monflier, E.; Blouet, E.; Barbaux, Y.; Mortreux, A. Wacker oxidation of 1-decene to 2-decanone in the presence of a chemically modified cyclodextrin system: A happy union of host-guest chemistry and homogeneous catalysis. Angew. Chem., Int. Ed. Engl. 1994, 33, 2100-2102. 
24. Monflier, E.; Tilloy, S.; Blouet, E.; Barbaux, Y.; Mortreux, A. Wacker oxidation of various olefins in the presence of per(2,6-di-O-methyl)- $\beta$-cyclodextrin: Mechanistic investigations of a multistep catalysis in a solvent free two phase system. J. Mol. Catal. A: Chem. 1996, 109, 27-35.

25. Monflier, E.; Tilloy, S.; Fremy, G.; Barbaux, Y.; Mortreux, A. A very useful and efficient Wacker oxidation of higher $\alpha$-olefins in the presence of per(2,6-di-O-methyl)- $\beta$-cyclodextrin. Tetrahedron. Lett. 1995, 36, 387-388.

26. Maksimov, A.L.; Sakharov, D.A.; Filippova, T.Y.; Zhuchkova, A.Y.; Karakhanov, E.A. Supramolecular catalysts on the basis of molecules-receptors. Ind. Eng. Chem. Res. 2005, 44, 8644-8653.

27. Karakhanov, E.A.; Filippova, T.Y.; Martynova, S.A.; Maximov, A.L.; Predeina, V.V.; Topchieva, I.N. New catalytic systems for selective oxidation of aromatic compounds by hydrogen peroxide. Catal. Today 1998, 44, 189-198.

28. Karakhanov, E.A.; Kardasheva, Y.; Kirillov, A.; Maximov, A.; Predeina, V.; Runova, E. Surface active macromolecular and supramolecular complexes: Design and catalysis. Macromol. Symp. 2000, 156, 137-145.

29. Tilloy, S.; Bricout, H.; Monflier, E. Cyclodextrins as inverse phase transfer catalysts for the biphasic catalytic hydrogenation of aldehydes: A green and easy alternative to conventional mass transfer promoters. Green Chem. 2002, 4, 188-193.

30. Monflier, E.; Tilloy, S.; Castanet, Y.; Mortreux, A. Chemically modified $\beta$-cyclodextrins: efficient supramolecular carriers for the biphasic hydrogenation of water-insoluble aldehydes. Tetrahedron Lett. 1998, 39, 2959-2960.

31. Hapiot, F.; Lyskawa, J.; Tilloy, S.; Bricout, H.; Monflier, E. Cyclodextrins or calixarenes: What is the best mass transfer promoter for Suzuki cross-coupling reactions in water? Adv. Synth. Catal. 2004, 346, 83-89.

32. Lacroix, T.; Bricout, H.; Tilloy, S.; Monflier, E. Chemically modified $\beta$-cyclodextrin as supramolecular carriers in biphasic palladium catalyzed cleavage of allylic carbonates: activity enhancement and substrate selective catalysis. Eur. J. Org. Chem. 1999, 11, 3127-3129.

33. Monflier, E.; Fremy, G.; Castanet, Y.; Mortreux, A. Molecular recognition between chemically modified $\beta$-cyclodextrin and dec-1-ene: New prospects for biphasic hydroformylation of waterinsoluble olefins. Angew. Chem. Int. Ed. Engl. 1995, 34, 2269-2271.

34. Monflier, E.; Tilloy, S.; Fremy, G.; Castanet, Y.; Mortreux, A. A further breakthrough in biphasic, rhodium catalyzed hydroformylation: the use of per(2,6-di-O-methyl)- $\beta$-cyclodextrin as inverse phase transfer catalyst. Tetrahedron Lett. 1995, 36, 9481-9484.

35. Kalck, P.; Miquel, L.; Dessoudeix, M. Various approaches to transfers improvement during biphasic catalytic hydroformylation of heavy alkenes. Catal. Today 1998, 42, 431-440.

36. Dessoudeix, M.; Urrutigoïty, M.; Kalck, P. Catalytic activity enhancement of a cyclodextrin/ water-soluble rhodium complex system due to its gradual supramolecular organization in the interphase. Eur. J. Inorg. Chem. 2001, 7, 1797-1800.

37. Mathivet, T.; Méliet, C.; Castanet, Y.; Mortreux, A.; Caron, L.; Tilloy, S.; Monflier, E. Rhodium catalyzed hydroformylation of water-insoluble olefins in the presence of chemically modified $\beta$-cyclodextrins: Evidence for ligand-cyclodextrin interactions and effect of various parameters on the activity and the aldehydes selectivity. J. Mol. Catal. A.: Chem. 2001, 176, 105-116. 
38. Dabbawala, A.A.; Parmar, J.N.; Jasra, R.V.; Bajaj, H.C.; Monflier, E. Cobalt catalyzed hydroformylation of higher olefins in the presence of chemically modified cyclodextrins. Catal. Commun. 2009, 10, 1808-1812.

39. Monflier, E.; Tilloy, S.; Bertoux, F.; Castanet, Y.; Mortreux, A. New prospects for the palladium catalyzed hydrocarboxylation of higher $\alpha$-olefins in two-phase system: The use of chemically modified- $\beta$-cyclodextrin. New J. Chem. 1997, 21, 857-859.

40. Tilloy, S.; Bertoux, F.; Mortreux, A.; Monflier, E. Chemically modified $\beta$-cyclodextrins in biphasic catalysis: a fruitful contribution of the host-guest chemistry to the transition-metal catalyzed reactions. Catal. Today 1999, 48, 245-253.

41. Behr, A.; Leschinski, J.; Awungacha, C.; Simic, S.; Knoth, T. Telomerization of butadiene with glycerol: Reaction control through process engineering, solvents, and additives. Chem. Sus. Chem. 2009, 2, 71-76.

42. Bricout, H.; Caron, L.; Bormann, D.; Monflier, E. Substrate selective catalysis in aqueous/ organic biphasic system with per(2,6-di-O-methyl)- $\beta$-cyclodextrin. Catal. Today 2001, 66, 355-361.

43. Torque, C.; Bricout, H.; Hapiot, F.; Monflier, E. Substrate-selective aqueous organometallic catalysis. How size and chemical modification of cyclodextrin influence the substrate selectivity. Tetrahedron 2004, 60, 6487-6493.

44. Cabou, J.; Bricout, H.; Hapiot, F.; Monflier, E. Methylated- $\beta$-cyclodextrins: Useful discriminating tools for substrate-selective reactions in aqueous organometallic catalysis. Catal. Commun. 2004, 5, 265-270.

45. Torque, C.; Sueur, B.; Cabou, J.; Bricout, H.; Hapiot, F.; Monflier, E. Substrate-selective aqueous organometallic catalysis. How small water-soluble organic molecules enhance the supramolecular discrimination. Tetrahedron 2005, 61, 4811-4817.

46. Leclercq, L.; Bricout, H.; Tilloy, S.; Monflier, E. Aqueous organometallic catalysis promoted by cyclodextrins. Can surface tension measurements explain the efficiency of chemically modified cyclodextrins? J. Colloid Interf. Sci. 2007, 307, 481-487.

47. Legrand, F.X.; Sauthier, M.; Flahaut C.; Hachani, J.; Elfakir, C.; Fourmentin, S.; Tilloy, S.; Monflier, E. Aqueous hydroformylation reaction mediated by randomly methylated $\beta$-cyclodextrin: How substitution degree influences catalytic activity and selectivity. J. Mol. Catal. A: Chem. 2009, 303, 72-77.

48. Sieffert, N.; Wipff, G. Adsorption at the liquid-liquid interface in the biphasic rhodium catalyzed hydroformylation of olefins promoted by cyclodextrins: A molecular dynamics study. J. Phys. Chem. B 2006, 110, 4125-4134.

49. Sieffert, N.; Wipff, G. Importance of interfacial adsorption in the biphasic hydroformylation of higher olefins promoted by cyclodextrins: A molecular dynamics study at the decene/water interface Chem. Eur. J. 2007, 13, 1978-1990.

50. Ding, L.; Jiao, X.; Deng, J.; Zhao, W.; Yang, W. Catalytic polymerizations of hydrophobic, substituted acetylene monomers in an aqueous medium by using a monomer/hydroxypropyl- $\beta$ cyclodextrin inclusion complexation. Macromol. Rapid Commun. 2009, 30, 120-125. 
51. Monflier, E.; Tilloy, S.; Méliet, C.; Mortreux, A.; Fourmentin, S.; Landy, D.; Surpateanu, G. First evidence of molecular recognition between cyclodextrins and a water-soluble ligand used in aqueous phase organometallic catalysis. New J. Chem. 1999, 23, 469-472.

52. Caron, L.; Tilloy, S.; Monflier, E.; Wieruszeski, J.M.; Lippens, G.; Fourmentin S.; Landy, D.; Surpateanu, G. Study of inclusion complexes of the $\beta$-cyclodextrin with the sodium salt of trisulfonated triphenylphosphine. J. Inclusion Phenom. 2000, 38, 661-679.

53. da Costa, A.; Monflier, E.; Landy, D.; Fourmentin, S.; Surpateanu, G. Scanning tunneling microscopy investigation of an inclusion complex between the $\beta$-cyclodextrin and the sodium salt of the trisulfonated triphenylphosphine. Surface Sci. 2001, 470, 275-283.

54. Caron, L.; Christine, C.; Tilloy, S.; Monflier, E.; Landy, D.; Fourmentin, S.; Surpateanu, G. One and two-dimensional NMR investigations of the inclusion of the monosulfonated triphenylphosphine in the $\beta$-cyclodextrin. Supramol. Chem. 2002, 14, 11-20.

55. Canipelle, M.; Caron, L.; Christine, C.; Tilloy, S.; Monflier, E. Thermodynamic insight into the origin of the inclusion of monosulfonated isomers of triphenylphosphine in the $\beta$-cyclodextrin. Carbohydr. Res. 2002, 337, 281-287.

56. Canipelle, M.; Tilloy, S.; Bricout, H.; Monflier, E. Complexation of monosulfonated triphenylphosphine with chemically modified $\beta$-cyclodextrins: Effect of substituents on the stability of inclusion complexes. J. Inclusion Phenom. 2005, 51, 79-85.

57. Binkowski, C.; Cabou, J.; Bricout, H.; Hapiot, F.; Monflier, E. Cleavage of water-insoluble alkylallylcarbonates catalyzed by a palladium/TPPTS/cyclodextrin system: Effect of phosphine/ cyclodextrin interactions on the reaction rate. J. Mol. Catal. A: Chem. 2004, 215, 23-32.

58. Monflier, E.; Bricout, H.; Hapiot, F.; Tilloy, S.; Aghmiz, A.; Masdeu-Bulto, A.M. High-Pressure ${ }^{31} \mathrm{P}\left\{{ }^{1} \mathrm{H}\right\}$ NMR studies of $\mathrm{RhH}(\mathrm{CO})(\mathrm{TPPTS})_{3}$ in the presence of methylated cyclodextrins: New light on rhodium catalyzed hydroformylation reaction assisted by cyclodextrins. Adv. Synth. Catal. 2004, 346, 425-431.

59. Blach, P.; Landy, D.; Fourmentin, S.; Surpateanu, G.; Bricout, H.; Ponchel, A.; Hapiot, F.; Monflier, E. Sulfobutyl ether- $\beta$-cyclodextrins: Promising supramolecular carriers for aqueous organometallic catalysis. Adv. Synth. Catal. 2005, 347, 1301-1307.

60. Kirschner, D.; Green, T.; Hapiot, F.; Tilloy, S.; Leclercq, L.; Bricout, H.; Monflier, E. Heptakis(2,3-di-O-methyl-6-O-sulfopropyl)- $\beta$-cyclodextrin: A genuine supramolecular carrier for the Aqueous Organometallic Catalysis. Adv. Synth. Catal. 2006, 348, 379-386.

61. Kirschner, D.; Jaramillo, M.; Green, T.; Hapiot, F.; Leclercq, L.; Bricout, H.; Monflier, E. Fine tuning of sulfoalkylated cyclodextrin structures to improve their mass-transfer properties in an aqueous biphasic hydroformylation reaction. J. Mol. Catal. A: Chem. 2008, 286, 11-20.

62. Ferreira, M.; Bricout, H.; Sayede, A.; Ponchel, A.; Fourmentin, S.; Tilloy, S.; Monflier, E. Biphasic aqueous organometallic catalysis promoted by cyclodextrins: How to design the water-soluble phenylphosphane to avoid interaction with cyclodextrin. Adv. Synth. Catal. 2008, 350, 609-618.

63. Legrand, F.X.; Hapiot, F.; Tilloy, S.; Guerriero, A.; Peruzzini, M.; Gonsalvi, L.; Monflier, E. Aqueous rhodium-catalyzed hydroformylation of 1-decene in the presence of randomly methylated $\beta$-cyclodextrin and 1,3,5-triaza-7-phosphaadamantane derivatives. Appl. Catal. A: General 2009, 362, 62-66. 
64. Tilloy, S.; Crowyn, G.; Monflier, E.; van Leeuwen, P.W.N.M.; Reek, J.N.H. Hydroformylation of 1-decene in aqueous medium catalyzed by rhodium/alkyl sulfonated diphosphines system in the presence of methylated $\beta$-cyclodextrins. How the flexibility of the diphosphine backbone influences the regioselectivity. New J. Chem. 2006, 30, 377-383.

65. Leclercq, L.; Hapiot, F.; Tilloy, S.; Ramkisoensing, K.; Reek, J.N.H.; van Leeuwen, P.W.N.M.; Monflier, E. Sulfonated Xantphos ligand and methylated cyclodextrin: A winning combination for rhodium catalysed hydroformylation of higher olefins in aqueous medium. Organometallics 2005, 24, 2070-2075.

66. Tilloy, S.; Hapiot, F.; Landy, D.; Fourmentin, S.; Michelet, V.; Genêt, J.P.; Monflier E. Watersoluble triphenylphosphane-3,3',3'’-tricarboxylate ( $m$-TPPTC) ligand and methylated cyclodextrins: a new combination for biphasic rhodium catalyzed hydroformylation of higher olefins. Adv. Synth. Catal. 2006, 348, 1547-1522.

67. Leclercq, L.; Sauthier, M.; Castanet, Y.; Mortreux, A.; Bricout, H.; Monflier, E. Two-phase hydroformylation of higher olefins using randomly methylated $\alpha$-cyclodextrin as mass transfer promoter: A smart solution for preserving the catalytic properties of the rhodium/trisulfonated triphenylphoshine catalytic system. Adv. Synth. Catal. 2005, 347, 55-59.

68. Sueur, B.; Leclercq, L.; Sauthier, M.; Castanet, Y.; Mortreux, A.; Bricout, H.; Tilloy, S.; Monflier, E. Rhodium complexes non-covalently bound to cyclodextrins: Novel water-soluble supramolecular catalysts for the biphasic hydroformylation of higher olefins. Chem. Eur. J. 2005, 11, 6228-6236.

69. Caron, L.; Canipelle, M.; Tilloy, S.; Bricout, H.; Monflier, E. Unexpected effect of cyclodextrins on water-soluble phosphine modified rhodium hydroformylation catalysts. Eur. J. Inorg. Chem. 2003, 595-599.

70. Binkowski-Machut, C.; Canipelle, M.; Bricout, H.; Tilloy, S.; Hapiot, F.; Monflier, E. Supramolecular trapping of phosphanes by cyclodextrins: A general approach to generate phosphane coordinatively unsaturated organometallic complexes. Eur. J. Inorg. Chem. 2006, 8, 1611-1619.

71. Machut, C.; Patrigeon, J.; Tilloy, S.; Bricout, H.; Hapiot, F.; Monflier, E. First example of self-assembled supramolecular bidentate ligands for aqueous organometallic catalysis. Angew. Chem. Int. Ed. 2007, 46, 3040-3042.

72. Caron, L.; Bricout, H.; Tilloy, S.; Ponchel, A.; Landy, D.; Fourmentin, S.; Monflier, E. Molecular recognition between a water-soluble organometallic complex and a $\beta$-cyclodextrin: First example of second-sphere coordination adducts possessing a catalytic activity. Adv. Synth. Catal. 2004, 346, 1449-1456.

73. Breslow, R.; Dong, S.D. Biomimetic reactions catalyzed by cyclodextrins and their derivatives. Chem. Rev. 1998, 98, 1997-2011.

74. Breslow, R.; Overman, L.E. Artificial enzyme combining a metal catalytic group and a hydrophobic binding cavity. J. Am. Chem. Soc. 1970, 92, 1075-1075.

75. Steinborn, D.; Junicke, H. Carbohydrate complexes of Platinum-group metals. Chem. Rev. 2000, 100, 4283-4317. 
76. McNaughton, M.; Engmann, L.; Birmingham, A.; Powis, G.; Cotgreave, I.A. Cyclodextrinderived diorganyl tellurides as glutathione peroxidase mimics and inhibitors of thioredoxin reductase and cancer cell growth. J. Med. Chem. 2004, 47, 233-239.

77. French, R.R.; Holzer, P.; Leuenberger, M.G.; Woggon, W.D. A supramolecular enzyme mimic that catalyzes the 15,15' double bond scission of $\beta, \beta$-carotene. Angew. Chem. Int. Ed. 2000, 39, 1267-1269.

78. Zhoua, Y.H.; Zhao, M.; Sun, H.; Mao, Z.W.; Ji, L.N. Effect of cyclodextrin dimers with bipyridyl and biphenyl linking groups on carboxyl ester hydrolysis catalyzed by zinc complex. $J$. Mol. Catal. A: Chem. 2009, 308, 61-67.

79. Tastan, P.; Akkaya, E.U. A novel cyclodextrin homodimer with dual-mode substrate binding and esterase activity. J. Mol. Catal. A: Chem. 2000, 157, 261-263.

80. Reetz, M.T.; Waldvogel, S.R. $\beta$-cyclodextrin-modified diphosphanes as ligands for supramolecular rhodium catalysts. Angew. Chem., Int. Ed. Engl. 1997, 36, 865-867.

81. Reetz, M.T. New approaches to supramolecular transition metal complexes. Top. Catal. 1997, 4, 187-200.

82. Reetz, M.T. New supramolecular transition metal catalysis. J. Heterocyclic Chem. 1998, 35, 1065-1073.

83. Reetz, M.T.; Frömbgen, C. Chemoselective reduction of halo-nitro aromatic compounds by $\beta$-cyclodextrin-modified transition metal catalysts in a biphasic system. Synthesis 1999, 9, 1555-1557.

84. Armspach, D.; Matt, D. Metal-capped $\alpha$-cyclodextrins: The crowing of the oligosaccharide torus with precious metals. Chem. Commun. 1999, 12, 1073-1074.

85. Deshpande, R.M.; Fukuoka, A.; Ichikawa, M. Novel phosphinite capped cyclodextrin rhodium catalyst in substrate selective hydroformylation. Chem. Lett. 1999, 28, 13-14.

86. Karakhanov, E.A.; Maksimov, A.L.; Runova, E.A.; Kardasheva, Y.S.; Terenina, M.V.; Buchneva, T.S.; Guchkova, A.Y. Supramolecular catalytic system based on calixarenes and cyclodextrins. Macromol. Symp. 2003, 204, 159-173.

87. Karakhanov, E.; Maximov, A.; Kirillov, A. Biphasic Wacker-oxidation of 1-octene catalyzed by palladium complexes with modified $\beta$-cyclodextrins. J. Mol. Catal. A: Chem. 2000, 157, 25-30.

88. Karakhanov, E.A.; Karapetyan, L.M.; Kardasheva, Y.S.; Maksimov, A.L.; Runova, E.A.; Skorkin, V.A.; Terenina, M.V. Molecular recognition and catalysis: from macrocyclic receptors to molecularly imprinted metal complexes. Macromol. Symp. 2006, 235, 39-51.

89. Schlatter, A.; Kundu, M.K.; Woggon, W.D. Enantioselective reduction of aromatic and aliphatic ketones catalyzed by ruthenium complexes attached to $\beta$-Cyclodextrin. Angew. Chem. Int. Ed. 2004, 43, 6731-6734.

90. Schlatter, A.; Woggon, W.D. Enantioselective transfer hydrogenation of aliphatic ketones catalyzed by ruthenium complexes linked to the secondary face of $\beta$-Cyclodextrin. Adv. Synth. Catal. 2008, 350, 995-1000.

91. Komiyama, M.; Hirai, H. Colloidal rhodium dispersions protected by cyclodextrins. Bull. Chem. Soc. Jpn. 1983, 56, 2833-2834.

92. Mandler, D.; Willner, I. Effective photoreduction of $\mathrm{CO}_{2} / \mathrm{HCO}_{3}{ }^{-}$to formate using visible light. $J$. Am. Chem. Soc. 1987, 109, 7884-7885. 
93. Willner, I.; Mandler, D. Characterization of $\mathrm{Pd}-\beta$-cyclodextrin colloids as catalysts in the photosensitized reduction of bicarbonate to formate. J. Am. Chem. Soc. 1989, 111, 1330-1336.

94. Huang, T.; Meng, F.; Qi, L. Facile synthesis and one-dimensional assembly of cyclodextrincapped gold nanoparticles and their applications in catalysis and surface-enhanced Raman scattering. J. Phys. Chem. C 2009, 113, 13636-13642.

95. Alvarez, J.; Liu, J.; Roman, E.; Kaifer, A.E. Water-soluble platinum and palladium nanoparticles modified with thiolated $\beta$-cyclodextrin. Chem. Commun. 2000, 1151-1152.

96. Liu, J.; Alvarez, J.; Ong, W.; Roman, E.; Kaifer, A.E. Tuning the catalytic activity of cyclodextrin modified palladium nanoparticles though host-guest binding interactions. Langmuir 2001, 17, 6762-6764.

97. Mhadgut, S.C.; Palaniappan, K.; Thimmaiah, M.; Hackney, S.A.; Török, B.; Liu, J. A metal nanoparticle-based supramolecular approach for aqueous biphasic reactions. Chem. Commun. 2005, 3207-3209.

98. Strimbu, L.; Liu, J.; Kaifer, A.E. Cyclodextrin-capped palladium nanoparticles as catalysts for the Suzuki reaction. Langmuir 2003, 19, 483-485.

99. Xue, C.; Palaniappan, K.; Arumugam, G.; Hackney, S.A.; Liu, J.; Liu, H. Sonogashira reactions catalyzed by water-soluble, $\beta$-cyclodextrin-capped palladium nanoparticles. Catal. Lett. 2007, 116, 94-100.

100. Nowicki, A.; Zhang, Y.; Léger, B.; Rolland, J.P.; Bricout, H.; Monflier, E.; Roucoux, A. Supramolecular shuttle and protective agent: A multiple role of methylated cyclodextrins in the chemoselective hydrogenation of benzene derivatives with ruthenium particles. Chem. Commun. 2006, 296-298.

101. Nowicki-Denicourt, A.; Ponchel, A.; Monflier, E.; Roucoux, A. Methylated Cyclodextrins: An efficient protective agent in water for zerovalent ruthenium nanoparticles and a supramolecular shuttle in alkene and arene hydrogenation reactions. J. Chem. Soc. Dalton Trans. 2007, 48, 5714-5719.

102. Hubert, C.; Denicourt-Nowicki, A.; Roucoux, A.; Landy, D.; Léger, B.; Crowyn, G.; Monflier, E. Catalytically active nanoparticles stabilized by host-guest inclusion complexes in water. Chem. Commun. 2009, 1228-1230.

103. Fornasier, R.; Marcuzzi, F.; Zorzi, D. High selectivity in the catalytic hydrogenation of acyl substituted pyridines in alkaline solution: Effect of complexation by $\beta$-cyclodextrin. J. Mol. Catal. 1987, 43, 21-26.

104. Shimizu, S.; Sasaki, Y.; Hirai, C. Inverse phase transfer catalysis by cyclodextrins. Palladium catalyzed reduction of bromoanisoles with sodium formate. Bull. Chem. Soc. Jpn. 1990, 63, 176-178.

105. Cassez, A.; Ponchel, A.; Bricout, H.; Fourmentin, S.; Landy, D.; Monflier, E. Eco-efficient catalytic hydrodechloration of carbon tetrachloride in aqueous cyclodextrin solutions. Catal. Lett. 2006, 108, 209-214.

106. Cassez, A.; Ponchel, A.; Hapiot, F.; Monflier, E. Unexpected multi-functional effects of methylated cyclodextrins in palladium charcoal-catalyzed Suzuki-Miyaura reaction. Org. Lett. 2006, 8, 4823-4826. 
107. Cassez, A.; Kania, N.; Hapiot, F.; Fourmentin, S.; Monflier, E.; Ponchel, A. Chemically modified cyclodextrins adsorbed on Pd/C particles: New opportunities to generate highly chemoand stereoselective catalysts for Heck reaction. Catal. Commun. 2008, 9, 1346-1351.

108. Ponchel, A.; Hapiot, F.; Tilloy, S.; Roucoux, A.; Monflier, E. Methylated cyclodextrins: New opportunities for aqueous catalysis. In Proceedings of the 14th International Cyclodextrins Symposium, Kyoto, Japan, May 8-11, 2008; pp. 60-66.

109. Senra, J.D.; Malta, L.F.B.; de Souza, A.L.F.; Medeiros, M.E.; Aguiar, L.C.S.; Antunes, O.A.C. Phosphine-free Heck reactions in aqueous medium using hydroxypropylated cyclodextrins as supramolecular hosts. Tetrahedron Lett. 2007, 48, 8153-8156.

110. Senra, J.D.; Malta, L.F.B.; Souza, A.L.F.; Aguiar, L.C.S.; Antunes, O.A.C. Palladium on calcium carbonate combined to 2-Hydroxypropyl- $\alpha / \beta$-cyclodextrins: A selective catalytic system for aqueous Heck coupling and hydroarylation. Adv. Synth. Catal. 2008, 350, 2551-2558.

111. Andreeva, L.V.; Maksimov, A.L.; Zhuchkova, A.Y.; Predeina, V.V.; Filippova, T.Y.; Karakhanov, E.A. Oxidation of unsaturated compounds in ionic liquids with the use of cyclodextrin-containing catalytic systems. Petrol. Chem. 2007, 47, 331-336.

112. Filardo, G.; di Blasi, M.; Galia A.; Ponchel, A.H.; Bricout, H.; Sayede, A.D.; Monflier, E. Peracetylated $\beta$-cyclodextrin as solubilizer of arylphosphines in supercritical carbon dioxide. $J$. Supercrit. Fluids 2006, 36, 173-181.

113. Galia, A.; Navarre, E.C.; Scialdone, O.; Ferreira, M.; Filardo, G.; Tilloy, S.; Monflier, E. Complexation of phosphine ligands with peracetylated- $\beta$-cyclodextrin in supercritical carbon dioxide: Spectroscopic determination of equilibrium constants. J. Phys. Chem. B 2007, 111, 2573-2578.

114. Tortosa-Estorach, C.; Giménez-Pedrós, M.; Masdeu-Bultó, A.M.; Sayede, A.D.; Monflier, E. Hydroformylation of 1-octene in supercritical carbon dioxide with rhodium alkyl P-donor ligands using a peracetylated $\beta$-cyclodextrin as solubiliser. Eur. J. Inorg. Chem. 2008, 46, 2659-2663.

115. Galia, A.; Navarre, E.C.; Scialdone, O.; Filardo, G.; Monflier, E. Complexation of phosphine ligands with peracetylated $\beta$-cyclodextrin in supercritical carbon dioxide: Effect of temperature and cosolvent on the equilibrium constant. J. Supercrit. Fluids 2009, 49, 154-160.

(C) 2009 by the authors; licensee Molecular Diversity Preservation International, Basel, Switzerland. This article is an open-access article distributed under the terms and conditions of the Creative Commons Attribution license (http://creativecommons.org/licenses/by/3.0/). 